\title{
NeEdLestick ACCIDENT RESULTING IN OCCUPATIONAL TRANSMISSION OF HCV: REPORT OF TWO CASES
}

\author{
Eunice Beatriz Martin Chaves ${ }^{1}$, Maria Carlota Borba Brum ${ }^{1}$, \\ Fabio Fernandes Dantas Filho', Marjana Denti Piana1, \\ Sheila Cardoso Toniasso ${ }^{1}$, Dvora Joveleviths ${ }^{1,2}$
}

\begin{abstract}
Occupational transmission of hepatitis $\mathrm{C}$ virus (HCV) through needlestick injury is a serious problem worldwide. Occupational transmission of $\mathrm{HCV}$ is estimated at an average rate between $0.5 \%$ and $0.75 \%$. There are factors associated with increased risk of transmission, such as deep injuries, procedures involving hollow-bore needle placement in the source patient's vein or artery, and high HCV RNA titer in the source patient. We describe two cases of HCV seroconversion in nursing assistants after different risk needlestick injuries.
\end{abstract}

Keywords: Needlestick injury; sharp injuries; HCV seroconversion; bloodborn pathogens; occupational transmission

Occupational exposure to bloodborne pathogens after needlestick injuries is a serious problem. The World Health Organization (WHO) estimates that more than 3 million health care workers (HCWs) will be exposed to sharp objects contaminated with hepatitis B virus (HBV), hepatitis C virus (HCV), or human immunodeficiency virus (HIV) every year ${ }^{1}$. HIV post-exposure prophylaxis (PEP) can reduce the risk of HIV transmission after needlestick injury, and the use of HBV vaccine and hepatitis B immune globulin is an effective method for preventing post-exposure HBV infection, but there is still no effective PEP for HCV infection².

The risk of infection associated with occupational exposures to HCV in the health care setting ranges from 0 to $10.3 \%$, with an average rate between $0.5 \%$ and $0.75 \% \%^{3,4}$. Occupational infections with $\mathrm{HCV}$ occur during adulthood, when the risk of severe long-term liver damage, including cirrhosis and hepatocarcinoma, is greater ${ }^{1}$. There are factors associated with increased risk, such as: deep injuries, procedures involving hollow-bore needle placement in the source patient's vein or artery, and high HCV RNA titer in the source patient $^{5,6}$, but the mechanisms involved in occupational transmission are not yet fully understood.

We describe two cases of HCV seroconversion in nursing assistants after needlestick injuries in two Brazilian hospitals. One case was supposed to be of high risk of transmission, and the other could be considered as posing a low risk.

\section{CASE 1}

In April 2007, a 34-year-old nursing assistant in a Brazilian hospital ward was injured with an insulin needle $(27.5 \mathrm{G} 1 / 2)$ on the left hand when administrating insulin to a patient. The HCW was using gloves at the time of the accident; the injury was superficial, with minor bleeding. The source-patient was HCV positive, with no information on HCV genotype, but was HIV and HBV negative. The HCW was HIV (anti-HIV), HBV (HbsAg) and HCV (anti-
Clin Biomed Res. 2015;35(4):243-245

1 Occupational Medicine Service, Hospital de Clínicas de Porto Alegre. Porto Alegre, RS, Brazil.

2 Universidade Federal do Rio Grande do Sul (UFRGS), Porto Alegre, RS, Brazil.

Corresponding author: Maria Carlota Borba Brum E-mail: mcarlotabrum@gmail.com Hospital de Clínicas de Porto Alegre Occupational Medicine Service Rua Ramiro Barcelos, 2350. 90035-903, Porto Alegre, RS, Brazil. 
HCV) negative, but had documented anti-HBs of 26 $\mathrm{mUI} / \mathrm{mL}$ (enzyme linked fluorescent assay, ELFA).

During follow-up, in June 2007, the HCW had an anti-HCV reagent, but no increase in alanine aminotransferase blood values, which reached $24 \mathrm{U} / \mathrm{L}$. (reference: 7 to $35 \mathrm{U} / \mathrm{L}$ ). A polymerase chain reaction (PCR) test for HCV (HCV-PCR-) was performed in July 2007, with positive result. The nursing assistant was asymptomatic during follow-up.

\section{CASE 2}

In July 2014, a 41 year-old nursing assistant in the emergency room was injured when attempting to puncture an agitated polytrauma patient with an intravenous catheter (Abbocath ${ }^{\circledR}$ T20, 20 G 1 1/4). The HCW was using gloves; the injury was deep, with moderate bleeding. She washed her hands with soap right after the needlestick injury, and kept pressing, squeezing and scrubbing the wound for about 10-15 minutes under running water.

At the time of the accident, the HCW was HIV (anti-HIV), HBV (HbsAg) and HCV (anti-HCV) negative, and had protective values of anti-HBs of $814 \mathrm{mUl} /$ $\mathrm{mL}$. The source patient was coinfected with HIV and $\mathrm{HCV}$, but with unknown HCV genotype.

HIV PEP was given for 4 weeks. Follow-up PEP-control exams were normal, and the HCW had no significant PEP side effects. Anti-HIV was negative after 45 days. The HCW did not attend for 90-day PEP monitoring. After 180 days, in January 2015, she tested positive for anti-HCV (ELISA) but negative for HCV-PCR-. In May 2015, a confirmatory
anti-HCV (ELISA) was positive, and, once again, -HCV-PCR tested negative.

\section{DISCUSSION}

Occupational transmission of $\mathrm{HCV}$ to $\mathrm{HCWs}$ is possible through percutaneous exposure ${ }^{7,8}$, mucocutaneous exposure ${ }^{9,10}$ and even nonintact skin ${ }^{11}$.

Although seroconversion occurred in case 2 in a setting of high risk of injury (needle in direct contact with source patient vein, deep wound, blood-filled needle, large hollow-bore needle and HIV coinfected source patient), a negative -HCV-PCR could be due to resolved $\mathrm{HCV}$ infection. There was no information on 90-day PEP control HCV-PCR. A second HCV-PCR, performed 4 months later, was also negative.

Possible seroconversion in case 1 occurred in a setting of low risk of needlestick injury (superficial injury, small hollow-bore needle, blood not visible in the sharp material, and no direct contact with source patient's vein or artery). This could be related to hypothetically high viral load of the source patient, although this information was not available at the moment.

Transmission of HCV through needlestick injury is considered to have very low rates and to be preventable by adopting standard precautions, such as the use of safety devices and proper disposal of sharps. Although there are some factors associated with increased risk, occupational transmission of $\mathrm{HCV}$ is not yet fully understood.

\section{Conflicts of interest}

The authors declare no conflicts of interest.

\section{REFERENCES}

1. Prüss-Üstün A, Rapiti E, Hutin Y. Sharps injuries: global burden of disease from sharps injuries to health-care workers. Geneva: World Health Organization; 2003. (WHO Environmental Burden of Disease Series, no. 3).

2. Askarian M, Yadollahi M, Kuochak F, Danaei M, Vakili V, Momeni M. Precautions for health care workers to avoid hepatitis $B$ and $C$ virus infection. Int J Occup Environ Med. 2011;2(4):191-8.

3. Kubitschke A, Bader C, Tillmann HL, Manns MP, Kuhn S, Wedemeyer H. Injuries from needles contaminated with hepatitis $C$ virus: how high is the risk of seroconversion for medical personnel really?. Internist (Berl). 2007;48(10):1165-72.

4. Jagger J, Puro V, De Carli G. Occupational transmission of hepatitis C virus. JAMA. 2002;288(12):1469-71.

5. Yazdanpanah Y, De Carli G, Migueres $B$, Lot F, Campins M, Colombo C, et al. Risk factors for hepatitis $C$ virus transmission to health care workers after occupational exposure: a European case-control study. Clin Infect Dis. 2005;41(10):1423-30.

6. Dore GJ, Kaldor JM, McCaughan GW. Systematic review of role of polymerase chain reaction in defining infectiousness among people infected with hepatitis $\mathrm{C}$ virus. BMJ. 1997;315(7104):333-7.

7. Herbert AM, Walker DM, Davies KJ, Bagg J. Occupationally acquired hepatitis $C$ virus infection. Lancet. 1992;339(8788):305.

8. Vaqlia A, Nicolin R, Puro V, Ippolito G, Bettini C, de Lalla F. Needlestick hepatitis $C$ virus seroconversion in a surgeon. Lancet. 1990;336(8726):1315-6.

9. Sartori M, Terra GL, Aglietta M, Manzin A, Navino C, Verzetti G. Transmission of hepatitis $C$ via blood splash into conjunctiva. Scand J Infect Dis. 1993;25(2):270-1. 
10. Ippolito G, Puro V, Petrosillo N, De Carli G, Micheloni G, Magliano E. Simultaneous infection with HIV and hepatitis $C$ virus following occupational conjunctival blood exposure. JAMA. 1998;280(1):28.

11. Beltrami EM, Kozak A, Williams IT, Saekhou AM, Kalish ML, Nainan
OV, et al. Transmission of HIV and hepatitis $\mathrm{C}$ virus from a nursing home patient to a health care worker. Am J Infect Control. 2003;31(3):168-75.

Received: Nov 14, 2015 Accepted: Nov 29, 2015 